Bull. Mater. Sci., Vol. 22, No. 7, December 1999, pp. 1037-1040. ( Indian Academy of Sciences.

\title{
Study on steel corrosion in different seabed sediments
}

\author{
YANTAO LI* and BAORONG HOU \\ Institute of Oceanology, Chinese Academy of Sciences, Qingdao, 266071 \\ MS received 10 September 1999
}

\begin{abstract}
A series of simulation experiments on carbon steel ( $A_{3}$ steel) and low alloy steel (16 Mn steel) in marine atmosphere (MA), seawater (SW) and seabed sediment (SBS) including rough sea sand, fine sea sand and seabed mud were carried out indoors for a year or so by means of individually hanging plates (IHP) and electrically connected hanging plates (ECHP). The corrosion of steels in SBS was mainly due to the macrogalvanic cell effect. The steel plates at the bottom of SBS, as the anode of a macrogalvanic cell, showed the heaviest corrosion with a corrosion rate of up to $0.12 \mathrm{~mm} / \mathrm{a}$, approximately equal to that of steel plates in marine atmosphere.

The test results showed that the corrosion rates of $A_{3}$ and $16 \mathrm{Mn}$ steel in marine environment were in the order: MA > SW > SBS by the IHP method; and MA > SBS > SW by the ECHP method. The corrosion rates of steels in the water/sediment interface were directly proportional to the grain size of the SBS by the ECHP method, but those of steels in the water/sediment interface did not vary with the grain size of SBS by the IHP method. The corrosion rate of low-alloy steel was a little higher than that of carbon steel. The results of this study have important applications for design of offshore steel structures such as oil platform, pier, and port.
\end{abstract}

Keywords. Seabed sediment; steel; corrosion behaviour.

\section{Introduction}

With the developing of oil exploitation and transportation, more and more steel structures-such as fixed platform for drilling oil, man-made island, steel pile wharf, seabed pipeline, etc-located in the marine environment which is usually divided into five zones (marine atmosphere zone, splash zone, tidal zone, immersion zone and seabed sediment zone) and in each of which corrosion rates are different. A lot of research has been carried out for a long time on steel corrosion in seawater (Hou Baorong et al 1997; Larrabee 1958; Schumacher 1979), but study on the effect of different offshore seabed sediment on steel corrosion has not been reported. In this study, the corrosion behaviotur of carbon steel and low-alloy steel in three different seabed sediments was investigated using the indoor simulation method.

\section{Test apparatus and material}

\subsection{Simulation experiment trough}

Plastic plates extending from the bottom of the trough divided the trough into 3 compartments, into each of which was placed sea sand, fine sea sand and sea mud respectively. Natural seawater was filled up to the middle

*Author for correspondence level of the trough, the upper level of which was marine atmosphere zone (figure 1).

\subsection{Materials}

The elemental composition of Chinese $A_{3}$ steel $(100 \mathrm{~mm} \times$ $50 \mathrm{~mm} \times 4 \mathrm{~mm})$ and $16 \mathrm{Mn}$ steel $(100 \mathrm{~mm} \times 50 \mathrm{~mm} \times$ $4 \mathrm{~mm}$ ) is given in table 1 .

\subsection{Seabed sediment}

Rough sea sand (10-20 mesh) and fine sea sand (60120 mesh) were collected from the First Bathing Beach in Qingdao; sea mud (clayey fine sand) was collected from Chengdao Beach in the Shengli Oilfields.

\subsection{Seawater}

Sand-filtered fresh natural seawater was collected from the seawater tank of the Institute of Oceanology, CAS.

\section{Experimental}

After the steel sample plates were pickled in $5 \% \mathrm{HCl}$ solution according to National Standard GB5776-86, they were suspended and electrically connected by wire. The connecting spots were welded with tin solder and sealed 
with epoxy resin. At the start of the experiment, the specimens were placed in the experimental trough as shown in figure 1; then rough sea sand, fine sea sand and sea mud sterilized by high temperature treatment (so that it was bacteria free) was put into the bottom of the trough, burying the three layers of test specimens evenly. Then fresh natural seawater was poured into the trough through the inlet above the seabed sediments, to immerse the test specimens, and the two layers of plates over them, to the level of the outlet from which the water flowed out. Inside the trough, proper circulation of seawater was ensured during the experiment.

\section{Results and discussion}

\subsection{The corrosion behaviour of individually hung and} electrically connected $A_{3}$ steel and $16 \mathrm{Mn}$ steel in three kinds of seabed sediments (rough sea sand, fine sea sand, and sea mud)

Figure 2 shows that the corrosion rates of $A_{3}$ steel specimens hanging individually were in the order: marine atmosphere > seawater > seabed sediment; the corrosion rates of $A_{3}$ steel specimens hanging electrically connected were in the order: marine atmosphere $>$ seabed sediment $>$ seawater. Under the same environmental conditions, when $16 \mathrm{Mn}$ steels were tested in the above two ways of hanging, the corrosion behaviour was almost the same as that of $A_{3}$ steel. This corrosion behaviour resulted from the coincident action of microcell and macrocell on the sample plates. The steel corrosion in marine environment-MA, SW, or SBS-is an oxygen consumption process with the corrosion rates controlled by oxygen diffusion (Kazuaki 1968). The steel corrosion rate in humid marine atmosphere was the fastest because the steel surface corroded under a thin electrolytic liquid film through which oxygen could easily diffuse to the steel surface through the electrolytic action of the local microcell. On the other hand, alternation of dryness and humidity could accelerate corrosion of steel with a rust layer

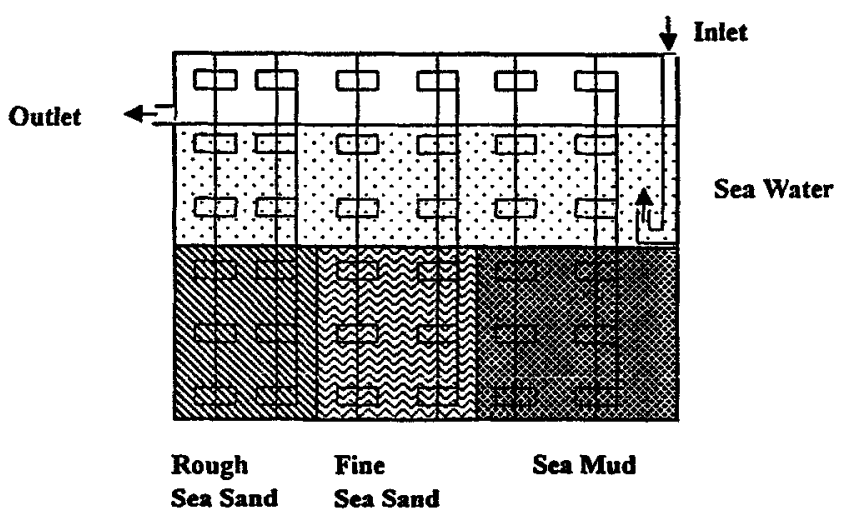

Figure 1. Trough for simulation experiment on offshore steel corrosion.
(Evans 1965, 1969; Kazuaki 1968). Because seawater flowed slowly in this test, steel corrosion mainly depended on the cathodic impedance, and was usually controlled by the rate of oxygen diffusion to the surface. The most serious corrosion zone was located at the zone with enough oxygen to the steel structure. Steel corrosion was mainly controlled by microcell electrolytic action caused by oxygen concentration difference.

In the seabed sediment zone, serious local corrosion occurred mainly because of the uneven oxygen diffusion macrocell between the steel specimens (Kazuaki 1968). The macrocell considered in this test was actually an oxygen concentration difference cell. The steel plates were protected as cathode where oxygen could diffuse to them while where oxygen could not easily diffuse to

Table 1. Elemental composition of $A_{3}$ and $16 \mathrm{Mn}$ steel.

\begin{tabular}{lcccccc}
\hline & \multicolumn{6}{c}{ Content (\%) } \\
\cline { 2 - 7 } Steel type & $\mathrm{C}$ & $\mathrm{Si}$ & $\mathrm{Mn}$ & $\mathrm{Cu}$ & $\mathrm{S}$ & $\mathrm{P}$ \\
\hline $\mathrm{A}_{3}$ & 0.16 & 0.20 & 0.46 & 0.036 & 0.006 & \\
$16 \mathrm{Mn}$ & 0.16 & 0.40 & 1.45 & 0.348 & 0.022 & 0.021 \\
\hline
\end{tabular}
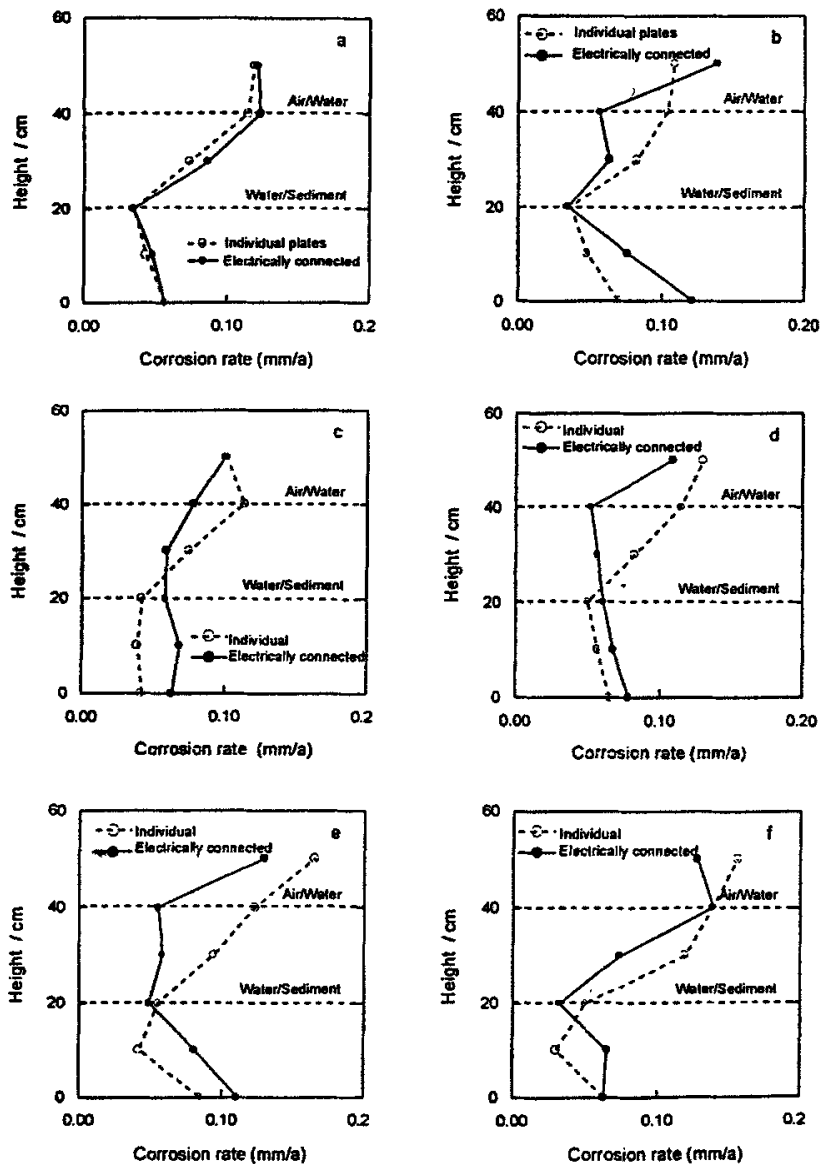

Figure 2. Corrosion rates of steel specimens by individual hanging method and electrically connected method. $A_{3}$ steel: a. rough sea sand; b. fine sea sand; c. sea mud. $16 \mathrm{Mn}$ steel: d. rough sea sand; $e$. fine sea sand; $f$. sea mud. 
the bottom of the seabed sediment, the steel plates there became anodes and were corroded acceleratedly. Because of the different corrosion mechanisms of the three zones, steel corrosion was lighter in the seawater/sea mud interface, where the oxygen diffusion rate was the lowest when the microcell was formed on the steel plate due to the even oxygen diffusion; the steel plates acted as cathode because oxygen could easily diffuse to them at the bottom. A macrocell was formed between the steel plates due to the uneven oxygen diffusion; two macrocells acted together and protected the steel plates. When the plates were hung electrically connectedly, the specimens in seawater were protected because the specimens exposed to marine atmosphere, seawater and sea sediment, were connected as a whole, and constituted a macrocell system.

\subsection{Effect of different sediments on corrosion of $A_{3}$ steel and $16 \mathrm{Mn}$ steel in the two methods of hanging plates}

Figure 3 shows that the corrosion behaviours of indi- vidually hanging or electrically connected hanging steel plates in Chengdao sea mud were almost the same; their corrosion rates had nothing to do with the depth at which the steel plates were located. But in sea sand, the corrosion rate of the lower specimen was very much higher than that of the two upper specimens. This was because the Chengdao sea mud was clayey fine, of small particle size and tight structure with poor oxygen permeation, so that oxygen diffusion to the steel plate surface at different depth was minimal, and formation of oxygen difference cell was difficult. But in rough sea sand, because the particle structure was loose, and oxygen could easily diffuse through it, the corrosion of steel plates as anode in the bottom was accelerated.

In the 60-120 mesh fine sea sand, because of the small particle size and the tight sand layer structure, and because oxygen diffusion decreases with depth, and also because oxygen diffusion to the bottom of the steel plates was minimal; the steel corrosion rate was accelerated to $0.12 \mathrm{~mm} / \mathrm{a}$, approaching that of steel plates in humid atmosphere.
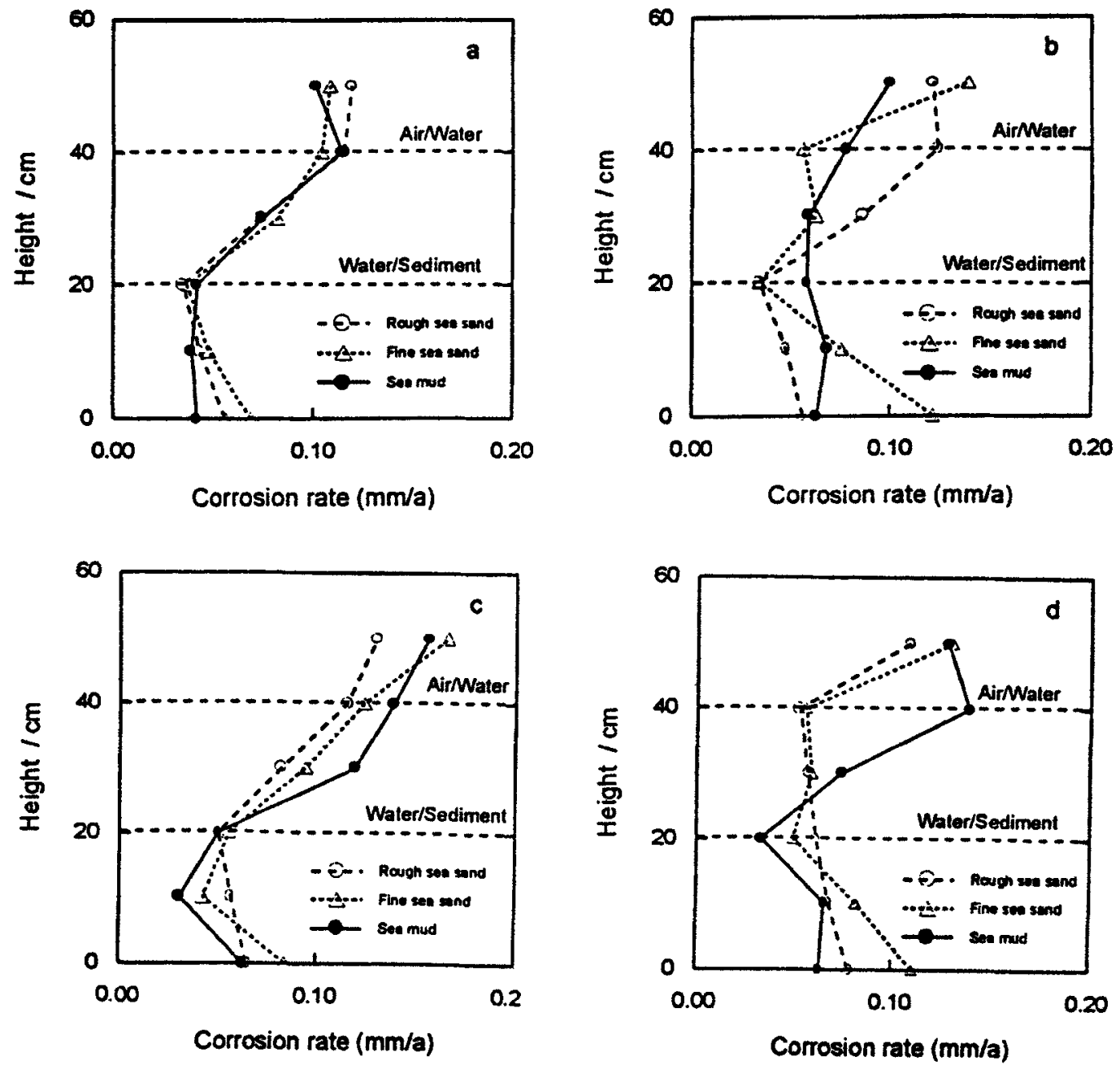

Figure 3. Corrosion rates of steels in different seabed sediments. $A_{3}$ steel: a. electrically connected hanging plates; b. individually hanging plates. $16 \mathrm{Mn}$ steel: c. electrically connected hanging plates; d. individually hanging plates. 
The corrosion rate of well-protected steel plates at the seawater/sea mud interface was almost the same as that of individually hanging plates. The corrosion rate of electrically connected hanging plates decreased with sediment particle size and was low because they constituted an integral part of a macrocell.

\section{Conclusions}

- The corrosion in seabed sediment was decided mainly by the macrogalvanic cell (oxygen concentration difference cell) caused by uneven oxygen diffusion between steel plates in different sediments and depth. Because the steel plates under the sediments became macroanodes, their corrosion rates at the bottom of the three different kinds of sediment were the highest. When the sediment was 60-120 mesh sea sand, the corrosion rate of the steel plates approached to almost that at the surface atmosphere, because of the formation of a small anode and big cathode macrocell between the upper and lower plates in sea sand.

- The corrosion rates of individually hanging plates in three corrosion zones were marine atmosphere $>$ seawater > seabed sediment; and those of electrically connected hanging plates were marine atmosphere $>$ seabed sediment $>$ seawater.

- The steel plates were best protected at the water/seabed sediment interface, where the corrosion was almost similar in the case of individually hanging steel plates, but positively related to decreasing seabed sediment size, in the case of electrically connected hanging steel plates.

- The corrosion rate of low-alloy steel was a little higher than that of carbon steel.

\section{References}

Evans U R 1965 Nature 206980

Evans U R 1969 Corrosion Sci. 9813

Hou Baorong et al 1997 Marine corrosion and corrosion control (Beijing: Science Press) pp 7-28

Kazuaki Zen 1968 Anti-corrosion Technol. 17102

Larrabee C P 1958 Corrosion 14501

Schumacher M 1979 Seawater corrosion handbook (New Jersey: Park Ridge) 1 p. 20 